\title{
Mutually exclusive groups of bronchitics and non-bronchitics in males
}

\author{
T. KHOSLA AND C. R. LOWE \\ Department of Medical Statistics and Department of Social and Occupational Medicine, Welsh National School of \\ Medicine, Cardiff
}

\begin{abstract}
SUMmarY
Seven mutually exclusive groups of non-bronchitics and chronic bronchitics are derived from 10,816 steel workers questioned and examined at Port Talbot. These groups are based on various combinations of responses to the Medical Research Council questionnaire on cough, phlegm, dyspnoea, increased cough and phlegm, and chest illness. The groups are formed on defined criteria of (1) a reasonable number of men in each group; (2) impairment of lung function $\left(F E V_{1}\right)$ related to the severity of chronic bronchitis symptoms; and (3) impairment of lung function from certain other diseases.

The ideal group of non-bronchitics (NB 0) answered 'no' to every symptomatology question $(46.4 \%)$. Non-bronchitics grade 1 (NB 1) were either symptom-free or had only occasional cough and phlegm with either or both increased cough and phlegm and chest illness (24.2\%). Non-bronchitics grade 2 (NB 2) complained of dyspnoea in the absence of persistent cough and phlegm (4.3\%). Chronic bronchitics grade 1 (CB 1) had persistent cough and phlegm in the absence of any other complaint $(11 \cdot 3 \%)$. Chronic bronchitics grade 2 (CB 2) had the additional impairment of increased cough and phlegm and/or chest illness (8.1\%). Grade 3 (CB 3) complained of dyspnoea with or without increased cough and phlegm (2.5\%). Grade 4 (CB 4) had both dyspnoea and chest illness (3.2\%).
\end{abstract}

Lung function $\left(F E V_{1}\right)$ in three of the groups of chronic bronchitics (CB 1, CB 2, CB $3: 21.9 \%$ ) was no worse than in the two groups of nonbronchitics with complaints of other respiratory disorders (NB 1, NB 2 : 28.6\%). An overall comparison on a binary division between non-bronchitics and bronchitics hides the severity of some of the bronchitic groups. For this reason it is recommended that epidemiological studies of chronic bronchitis should separate the suggested grades of bronchitics (CB 1, 2, 3, and 4) and compare them with the ideal group of non-bronchitics (NB $0: 46 \cdot 4 \%$ ) which has the lowest prevalence of heart trouble and asthma and those who have had pneumonia.

\section{INTRODUCTION}

The Medical Research Council's Committee on the Aetiology of Chronic Bronchitis approved the use of a standard questionnaire in 1960 and this was slightly modified in 1966 . So far the MRC haso published two booklets giving instructions on the use of the questionnaire $(1960,1966)$. Matters relating to observer variation, reproducibility, and standardization of the questionnaire have beent reported in more than 30 publications. In a review article Stuart-Harris (1968) has listed about 400 research papers on chronic bronchitis published between 1951 and 1967. The questionnaire has been extensively used by research workers in Englishspeaking countries and it has been translated into more than 12 languages. The MRC has approved two types of questionnaire, short and long. In this paper attention is focussed on respiratory symptomatology as defined in the short questionnaire.

. The diagnosis of chronic bronchitis is based on the response to the symptomatology part of the questionnaire (Table I). Very broadly the questions are divided into three parts:

(1) on cough (Nos. 1, 3, 5)

(2) on plegm (Nos. 6, 8, 10)

(3) on complications arising from:

(a) increased cough and phlegm (12a)

(b) recent chest illness (21)

(c) shortness of breath (14b).

For purposes of standardization the MRC has recommended three grades of cough, based on the response to questions 1, 3, and 5 (Table I). Quite independently of cough, three grades of phlegm are defined, based on the response to questions 6,8 , and 10. The recommended grades on the severity 
TABLE I

SYMPTOMATOLOGY QUESTIONS

\begin{tabular}{|c|c|}
\hline $\begin{array}{l}\text { MRC (1960) } \\
\text { Question No. }\end{array}$ & \\
\hline 1 & you usually cough first thing in the morning \\
\hline 3 & Mornings apart, do you usually cough at any time \\
\hline 5 & Do you cough like this for most days for as much as \\
\hline 6 & Do you usually bring up any phlegm from your \\
\hline 8 & $\begin{array}{l}\text { Mornings apart, do you usually bring up phlegm } \\
\text { from your chest at any time during the day or } \\
\text { at night in the winter? }\end{array}$ \\
\hline 10 & $\begin{array}{l}\text { Do you bring up phlegm like this on most days for } \\
\text { as much as three months each year? }\end{array}$ \\
\hline $12 \mathrm{a}$ & $\begin{array}{l}\text { In the past three years have you had a period of } \\
\text { (increased) cough and phlegm lasting for three } \\
\text { weeks or more? }\end{array}$ \\
\hline 21 & $\begin{array}{l}\text { In the past three years have you had any chest } \\
\text { illness which has kept you off work for as much }\end{array}$ \\
\hline $14 b$ & $\begin{array}{l}\text { Do you usually get short of breath walking with } \\
\text { other people at an ordinary pace on the level? }\end{array}$ \\
\hline
\end{tabular}

of cough are mutually exclusive, and the classification of grade is based on defined sets of responses to the questions (Table II). On similar lines, three grades of phlegm are defined. But so far no attempt appears to have been made to grade the severity of chronic bronchitis into mutually exclusive groups using all the questions. Such gradings are necessary because the symptoms of chronic bronchitis and related disorders vary greatly in severity from an occasional cough with no expectoration to persistent and purulently productive cough with disabling breathlessness. Three overlapping categories of bronchitis proposed by different investigators are listed in the MRC booklet (persistent cough and phlegm, persistent cough and phlegm with recent chest illness, and the chronic bronchitis syndrome).

TABLE II

SETS OF $2^{3}$ RESPONSES TO QUESTIONS ON COUGH

\begin{tabular}{|c|c|c|c|}
\hline \multicolumn{3}{|c|}{$\begin{array}{l}\text { Sets of Responses to } \\
\text { Questions on Cough } \\
\text { (Question No.) }\end{array}$} & \multirow{2}{*}{$\begin{array}{l}\text { MRC Grades } \\
\text { of Cough }\end{array}$} \\
\hline 1 & 3 & 5 & \\
\hline $\begin{array}{l}\text { No } \\
\text { No } \\
\text { Yes } \\
\text { Yes }\end{array}$ & $\begin{array}{l}\text { No } \\
\text { Yes } \\
\text { No } \\
\text { Yes }\end{array}$ & $\begin{array}{l}\text { No } \\
\text { No } \\
\text { No } \\
\text { No }\end{array}$ & Grade 0 \\
\hline No & No & Yes & Inconsistent response \\
\hline $\begin{array}{l}\text { No } \\
\text { Yes }\end{array}$ & $\begin{array}{l}\text { Yes } \\
\text { No }\end{array}$ & $\begin{array}{l}\text { Yes } \\
\text { Yes }\end{array}$ & Grade 1 \\
\hline Yes & Yes & Yes & Grade 2 \\
\hline
\end{tabular}

\section{SOURCES OF DATA}

The aetiology of chronic bronchitis is still not completely elucidated. The geographical variation in Wales itself is quite marked (SMR Wales 1-132; Wales II-79). Much of the variation is probably explained by differences in urbanization and industrialization between the two regions of Wales. In Wales I the coal and the iron and steel industries are of major importance as sources of employment. But statistical analysis of occupational factors is complicated and difficult because of the interrelationship, among other known associated factors, of smoking habits, social class, age, years of exposure, the selective migration of physically unfit workers to less hazardous occupations, and the severity of chronic bronchitis. We have used the short respiratory symptom questionnaire on about 8,000 steel workers at Ebbw Vale and over 10,000 at Port Talbot in a survey of bronchitis in the steel industry. A full description of the methods by which the information was collected is given in an earlier paper (Lowe et al., 1968). Here it is sufficient to mention that our questionnaire included information on variables such as age, marital status, size of family, area of residence, history of present and past occupations, history of diseases (asthma, pneumonia, heart trouble), smoking habits, and measurements of height, weight, and lung function.

As this paper is concerned with the methodology of defining mutually exclusive groups of bronchitics and non-bronchitics, all the available information (but excluding known pneumoconiotics) collected at the two steel works is used for our study. But for conciseness the complete results are presented for Port Talbot.

\section{Desirable Criteria of Mutually Exclusive GrouPS}

The grading of bronchitis is based on the response to the set of nine binary questions on respiratory symptoms (Table I). Theoretically there are 29 (512) groups, including combinations of some inconsistent answers (for example NO to questions 1 and 3 and YES to question 5). Obviously the number of groups is much too large to be of practical use. What is needed are agreed criteria to define a minimum number of groups compatible with the following considerations:

1. that there are reasonable numbers of observations within each group;

2. that lung function measurements are progressively impaired with the severity of chronic bronchitis; 
TABLE III

DISTRIBUTION OF 24 MUTUALLY EXCLUSIVE GROUPS BASED ON ANSWERS TO RESPIRATORY QUESTIONS OF TABLE I AT PORT TALBOT

\begin{tabular}{|c|c|c|c|c|c|c|c|c|}
\hline \multirow{2}{*}{\multicolumn{2}{|c|}{ Row No. }} & \multirow[b]{2}{*}{$\begin{array}{l}\text { Dyspnoea } \\
\text { Q. 14B }\end{array}$} & \multirow[b]{2}{*}{$\begin{array}{c}\text { Increased } \\
\text { Cough and Phlegm } \\
\text { Q. 12A }\end{array}$} & \multirow{2}{*}{$\begin{array}{l}\text { (3) } \\
\text { Chest } \\
\text { Illness } \\
\text { Q.21 }\end{array}$} & \multicolumn{2}{|c|}{ (4) No Bronchitis (5) } & \multirow{2}{*}{$\begin{array}{c}\text { (6) } \\
\text { Bronchitis } \\
\begin{array}{c}\text { Persistent Cough } \\
\text { and Phlegm }\end{array} \\
\begin{array}{c}\text { Yes to } \\
\text { Q. 1, 3, 5, 6, 8, } 10\end{array}\end{array}$} & \multirow{2}{*}{$\begin{array}{c}\text { (7) } \\
\text { Total }\end{array}$} \\
\hline & & & & & \multirow{2}{*}{$\begin{array}{c}\begin{array}{c}\text { Symptom-free } \\
\text { No to }\end{array} \\
\text { Q. 1, 3, 5, 6, 8, } 10 \\
5,017 \text { G1 } \\
\end{array}$} & $\begin{array}{c}\text { Occasional } \\
\text { Cough or Phlegm } \\
\text { No to Q. } 5,10 \\
\text { and Yes to at least } \\
\text { one of } 1,3,6,8\end{array}$ & & \\
\hline $1 .$. & .. & No & No & No & & $1,320 \mathrm{G} 2$ & 1,222 G5 & 7,559 \\
\hline 2.. & .. & No & Yes & No & 293 & $161 \mathrm{G} 3.1$ & 345 G6.1 & 799 \\
\hline $3 .$. & .. & No & No & Yes & 340 & $170 \mathrm{G} 3.2$ & 213 G6.2 & 723 \\
\hline $4 .$. & .. & No & Yes & Yes & 203 & $139 \mathrm{G3.3}$ & 323 G6.3 & 665 \\
\hline $5 .$. & .. & Yes & No & No & 159 & $125 \mathrm{G} 4.1$ & 176 G7.1 & 460 \\
\hline 6. & .. & Yes & Yes & No & $\overline{14}$ & $22 \mathrm{G} 4.2$ & 90 G7.2 & 126 \\
\hline $7 .$. & . & Yes & No & Yes & $\overline{35}$ & $35 \mathrm{G} 4.3$ & 93 G7.3 & 163 \\
\hline 8.. & .. & Yes & Yes & Yes & 41 & $32 \mathrm{G} 4.4$ & 248 G7.4 & 321 \\
\hline $9 .$. & .. & & Total & & 6,102 & 2,004 & 2,710 & 10,816 \\
\hline
\end{tabular}

3. that lung function measurements are also impaired in certain other respiratory diseases, such as asthma and heart trouble.

Criterion 3 above implies that different disease conditions should be kept separate even though they may have identical degrees of impairment of lung function as measured by $\mathrm{FEV}_{1}$, FVC or FEV \%.

\section{RESULTS}

Table III gives the distribution of 24 mutually exclusive sets of responses to the symptomatology questionnaire of Table $I$ in relation to 10,816 steel workers questioned and examined at Port Talbot. These groups are based on the combination of responses to questions on cough, phlegm, and complaints of dyspnoea, increased cough and phlegm, and chest illness. It is felt that any further subdivisions of the groups would impose unnecessary complications.

Group $\mathrm{G}_{1}$, consisting of 5,017 persons (46.4\%), were symptom-free on each of the nine questions (NO to questions $1,3,5,6,8,10$ of Table I) and group $\mathbf{G}_{2}$ (first entry under column 5 ), consisting of 1,320 persons $(12 \cdot 2 \%)$, complained of only occasional cough and/or phlegm. The remaining entries under columns 4 and 5 pertain to subgroups of other non-bronchitics with one or more additional complaints arising from dyspnoea, increased cough and phlegm, and chest illness.

Because of small relative frequencies (criterion 1) the subgroups consisting of 293 and 161 are combined to form a group $G_{3.1}$ totalling 454 persons $(4 \cdot 2 \%)$ who are either symptom-free or had only occasional cough and/or phlegm but had a common complaint of increased cough and phlegm. Similarly, six other non-bronchitic groups are formed $\left(\mathbf{G}_{3 \cdot 2^{-}}\right.$ $\mathrm{G}_{4.4}$ ) by combining the horizontal entries under columns 4 and 5. Apart from small numbers, it is also felt that in the presence of other complaints (columns 1,2,3) there would be little difference between groups who are symptom-free (column 4) and those who have occasional cough and/or phlegm (column 5).

Table IV gives the relative frequency distribution of the 17 subgroups of non-bronchitics and bronchitics derived from Table III. The Table also gives the percentages of other respiratory complaints within the group.

The results shown in Table IV are derived from all the men surveyed at Port Talbot. However, because lung function tests based on ventilatory measurements $\left(\mathrm{FEV}_{1}, \mathrm{FVC}\right.$, and $\left.\mathrm{FEV} \%\right)$ are dependent on age and height, any comparison among the various subgroups of non-bronchitics and bronchitics must necessarily adjust for age and height.

Table $\mathrm{V}$ gives for each of the 17 subgroups at Port Talbot the mean values of the related variables of age, height, FEV, FVC, and FEV \%. The range of mean age varies from 40.5 years $\left(\mathrm{G}_{3.1}\right)$ to $51 \cdot 2$ years $\left(G_{7.4}\right)$ and mean $F E V_{1}$ from $2 \cdot 29\left(G_{7.4}\right)$ to 3.68 litres $\left(G_{1}\right)$. An appreciable part of the difference can be attributed to the composition of group $G_{1}$ who on average are both younger and taller.

\section{Lung Function, Age, Height}

On average lung function measurements decrease with age, and within age groups $\mathrm{FEV}_{1}$ and FVC 
TABLE IV

PERCENTAGES OF ASTHMA, HEART TROUBLE, AND THOSE WHO HAVE HAD PNEUMONIA WITHIN SYMPTOMATOLOGY GROUPS

\begin{tabular}{|c|c|c|c|c|c|c|}
\hline \multicolumn{3}{|c|}{ Symptomatology Group } & Relative Frequency & Asthma & Heart Trouble & Pneumonia \\
\hline \multicolumn{3}{|c|}{$\begin{array}{l}\text { Non-bronchitics } \\
\mathbf{G} 1 . .\end{array}$} & $46 \cdot 38$ & 1.4 & $2 \cdot 0$ & $10 \cdot 8$ \\
\hline G $2 \ldots$ & .. &.. & $12 \cdot 20$ & 1.5 & $2 \cdot 7$ & $13 \cdot 2$ \\
\hline $\begin{array}{l}\text { G } 3.1 \\
\text { G } 3.2 \\
\text { G } 3.3\end{array}$ & .. & $\begin{array}{l}. . \\
. .\end{array}$ & $\begin{array}{l}4 \cdot 20 \\
4 \cdot 71 \\
3 \cdot 16\end{array}$ & $\begin{array}{l}2.0 \\
5.5 \\
5.6\end{array}$ & $\begin{array}{l}3 \cdot 7 \\
3 \cdot 1 \\
4 \cdot 1\end{array}$ & $\begin{array}{l}14 \cdot 1 \\
21 \cdot 2 \\
23 \cdot 7\end{array}$ \\
\hline $\begin{array}{l}\text { G } 4.1 \\
\text { G } 4.2 \\
\text { G } 4.3 \\
\text { G } 4.4\end{array}$ & $\begin{array}{l}. . \\
. .\end{array}$ & $\begin{array}{l}. \\
\because \\
.\end{array}$ & $\begin{array}{l}2.63 \\
0.33 \\
0.65 \\
0.67\end{array}$ & $\begin{array}{l}2 \cdot 8 \\
5 \cdot 6 \\
7 \cdot 1 \\
9 \cdot 6\end{array}$ & $\begin{array}{r}14.8 \\
16.7 \\
12.9 \\
6.8\end{array}$ & $\begin{array}{l}14 \cdot 8 \\
33 \cdot 3 \\
25 \cdot 7 \\
28 \cdot 8\end{array}$ \\
\hline \multicolumn{3}{|c|}{$\begin{array}{c}\text { Bronchitics } \\
\text { G 5 . } \\
\text { G } 6.1 \\
\text { G } 6.2 \\
\text { G } 6.3 \\
\text { G } 7.1 \\
\text { G } 7.2 \\
\text { G } 7.3 \\
\text { G } 7.4\end{array}$} & $\begin{array}{r}11 \cdot 30 \\
3 \cdot 19 \\
1.97 \\
2.99 \\
1.63 \\
0.83 \\
0.86 \\
2 \cdot 29\end{array}$ & $\begin{array}{l}3 \cdot 1 \\
3 \cdot 5 \\
6.1 \\
7 \cdot 4 \\
3 \cdot 4 \\
6 \cdot 7 \\
9 \cdot 7 \\
9 \cdot 3\end{array}$ & $\begin{array}{r}2 \cdot 1 \\
2.9 \\
3.8 \\
6.8 \\
11.9 \\
5.6 \\
10.8 \\
14.5\end{array}$ & $\begin{array}{l}16 \cdot 4 \\
17 \cdot 1 \\
22 \cdot 1 \\
21 \cdot 1 \\
17 \cdot 6 \\
13 \cdot 3 \\
34 \cdot 4 \\
34 \cdot 7\end{array}$ \\
\hline Total .. & .. & .. & $\begin{array}{l}100 \\
(10,816)\end{array}$ & & & \\
\hline
\end{tabular}

TABLE V

MEAN VALUES OF SOME VARIABLES BY SYMPTOMATOLOGY GROUPS (PORT TALBOT MALES)

\begin{tabular}{|c|c|c|c|c|c|c|}
\hline Group & No. & Mean Age (yr) & Mean Height (in) & Mean $\mathrm{FEV}_{1}(1)$. & Mean FVC(1.) & Mean FEV\% \\
\hline G 1 & 5,017 & $40 \cdot 6$ & $67 \cdot 6$ & 3.68 & $4 \cdot 60$ & 79.9 \\
\hline G 2 & 1,320 & $42 \cdot 5$ & $67 \cdot 3$ & $3 \cdot 40$ & 4.41 & $76 \cdot 8$ \\
\hline $\begin{array}{l}\text { G } 3.1 \\
\text { G } 3.2 \\
\text { G } 3.3\end{array}$ & $\begin{array}{l}454 \\
510 \\
342\end{array}$ & $\begin{array}{l}40 \cdot 5^{L} \\
42 \cdot 3 \\
43 \cdot 4\end{array}$ & $\begin{array}{l}67.7 \\
67.6 \\
67.7^{\mathrm{H}}\end{array}$ & $\begin{array}{l}3.57 \\
3.41 \\
3 \cdot 36\end{array}$ & $\begin{array}{l}4.55 \\
4.40 \\
4.37\end{array}$ & $\begin{array}{l}78 \cdot 4 \\
77.0 \\
76 \cdot 6\end{array}$ \\
\hline $\begin{array}{l}\text { G } 4.1 \\
\text { G } 4.2 \\
\text { G } 4.3 \\
\text { G } 4.4\end{array}$ & $\begin{array}{r}284 \\
36 \\
70 \\
73\end{array}$ & $\begin{array}{l}49 \cdot 0 \\
50 \cdot 3 \\
49 \cdot 5 \\
49 \cdot 9\end{array}$ & $\begin{array}{l}66 \cdot 7 \\
66 \cdot 4 \\
67 \cdot 6 \\
66 \cdot 7\end{array}$ & $\begin{array}{l}2.98 \\
2.72 \\
2 \cdot 86 \\
2 \cdot 58\end{array}$ & $\begin{array}{l}3 \cdot 88 \\
3 \cdot 79 \\
3 \cdot 91 \\
3 \cdot 62\end{array}$ & $\begin{array}{l}76 \cdot 6 \\
71.1 \\
71 \cdot 7 \\
69.8\end{array}$ \\
\hline G 5 & 1,222 & $42 \cdot 4$ & $67 \cdot 2$ & $3 \cdot 36$ & $4 \cdot 36$ & $76 \cdot 7$ \\
\hline $\begin{array}{l}\text { G } 6.1 \\
\text { G } 6.2 \\
\text { G } 6.3\end{array}$ & $\begin{array}{l}345 \\
213 \\
323\end{array}$ & $\begin{array}{l}42 \cdot 3 \\
44 \cdot 3 \\
45 \cdot 7\end{array}$ & $\begin{array}{l}67 \cdot 3 \\
67 \cdot 4 \\
67 \cdot 3\end{array}$ & $\begin{array}{l}3 \cdot 36 \\
3 \cdot 07 \\
3 \cdot 05\end{array}$ & $\begin{array}{l}4 \cdot 42 \\
4 \cdot 21 \\
4 \cdot 17\end{array}$ & $\begin{array}{l}75 \cdot 7 \\
72 \cdot 2 \\
72 \cdot 4\end{array}$ \\
\hline $\begin{array}{ll}\text { G 7.1 } & \\
\text { G 7.2 } & \because \\
\text { G 7.3 } & \because \\
\text { G } 7.4 & \because\end{array}$ & $\begin{array}{r}176 \\
90 \\
93 \\
248\end{array}$ & $\begin{array}{l}50 \cdot 1 \\
49 \cdot 9 \\
49 \cdot 7 \\
51 \cdot 2^{\mathrm{H}}\end{array}$ & $\begin{array}{l}66.8 \mathrm{~L} \\
66 \cdot 4^{\mathrm{L}} \\
67.0 \\
66 \cdot 8\end{array}$ & $\begin{array}{l}2 \cdot 80 \\
2 \cdot 70 \\
2 \cdot 45 \\
2 \cdot 29\end{array}$ & $\begin{array}{l}3.79 \\
3.71 \\
3 \cdot 54 \\
3.41\end{array}$ & $\begin{array}{l}73 \cdot 2 \\
71 \cdot 7 \\
67 \cdot 5 \\
65 \cdot 6\end{array}$ \\
\hline $\begin{array}{l}\text { Range of } \\
\text { means }\end{array}$ & & $\frac{40 \cdot 5}{51 \cdot 2}$ & $\frac{66 \cdot 4}{67 \cdot 7}$ & $\frac{2 \cdot 29}{3 \cdot 68}$ & $\frac{3.41}{4.60}$ & 65.6 \\
\hline
\end{tabular}

increase with height. The usual method of adjustment for age and height is time consuming. It has been shown elsewhere (Khosla, 1971) that in adults the following indices of ventilatory functions are invariant with respect to age and height:

$$
\begin{aligned}
& \text { Index } \mathrm{FEV}_{1}=\frac{\mathrm{FEV}_{1} \text { Age }}{\text { Height }^{2}} \\
& \text { Index FVC }=\frac{\text { FVC Aget }}{\text { Height }^{2}} \\
& \text { Index FEV } \%=\text { FEV } \% \text { Age }
\end{aligned}
$$

These indices have been suggested for use in epidemiological studies because the 'standard' values of forced expiratory volume have ethnic labels attached to them (Caucasians, etc.) and in this sense lack universal applicability. The proposed indices of ventilatory functions are based on theoretical considerations and have now been validated in a different population from Poland (Jędrychowski and Księżyk, 1973).

Table VI gives the means and standard deviations of the indices for each of the 17 symptomatology groups surveyed at Port Talbot. Figure 1 gives for the 
TABLE VI

MEAN VALUES OF VENTILATORY INDICES BY SYMPTOMATOLOGY GROUPS (PORT TALBOT MALES)

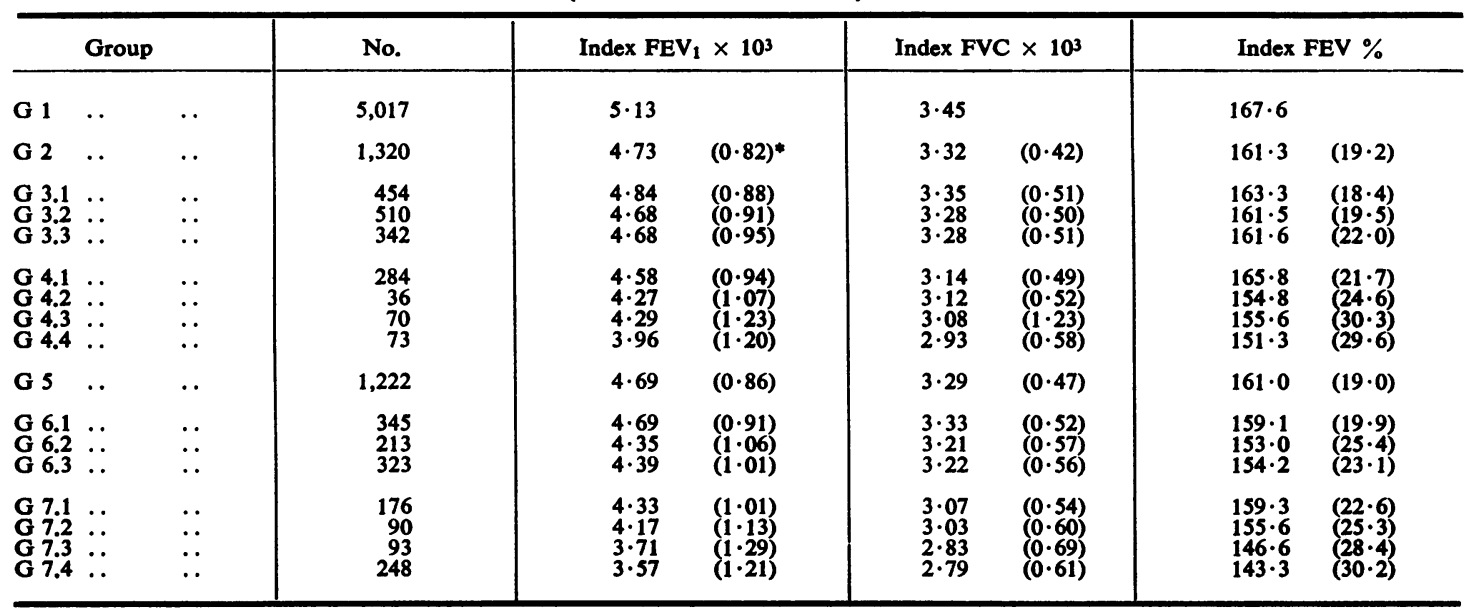

* Standard deviations are given in parentheses.

Standard deviations for group G1 are not available. The standard deviations are expected to be of the same order as that of group G2.

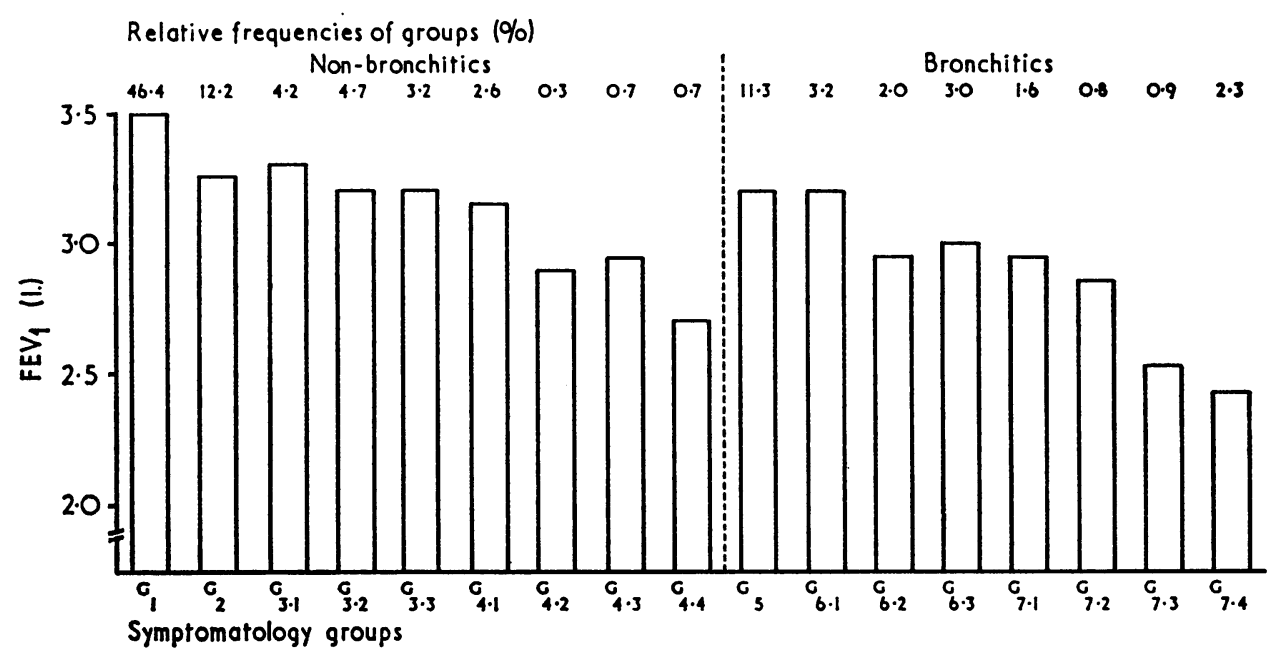

Fio. 1. Adjusted FEV 1 (at age 45 years and height 68 inches) and symptomatology groups.

Port Talbot population the bar chart of recomputed values of FEV 1 at age 45 years and height 68 inches by uniformly multiplying each of the mean FEV 1 indices by a constant factor $689 \cdot 3^{*}$. The figure highlights the following points:

1. Certain subgroups of non-bronchitics $\left(G_{2}\right.$, $G_{3 \cdot 1}, G_{3 \cdot 2}, G_{3 \cdot 3}$, and $\left.G_{4 \cdot 1}\right)$ have almost identical FEV $_{1}$ values.
2. Similarly, certain subgroups of bronchitics have almost identical values $\left(G_{5}\right.$ and $G_{6.1} ; \mathbf{G}_{6.2}$, $\mathbf{G}_{6 \cdot 3}, \mathbf{G}_{7 \cdot 1}, \mathbf{G}_{7 \cdot 2}$ ).

3. The first two subgroups of bronchitics ( $G_{5}$ and $G_{6.1}$ ) have a poorer lung function than the 'ideal' group of non-bronchitics (symptom-free $\mathbf{G}_{1}$ ) but a better one than the three later subgroups of non-bronchitics $\left(\mathbf{G}_{4 \cdot 2}, \mathbf{G}_{4.3}, \mathbf{G}_{4 \cdot 4}\right)$.

4. Many groups replying YES to the question on increased cough and phlegm do not appear to 
have any additional impairment of lung function compared with the corresponding groups replying $\mathrm{NO}$ to the question $\left(\mathrm{G}_{2}\right.$ and $\mathrm{G}_{3.1} ; \mathrm{G}_{3.2}$ and $\mathrm{G}_{3.3}$; $G_{5}$ and $G_{6.1} ; G_{6.2}$ and $G_{6.3}$ ). In the presence of dyspnoea, however, the question on increased cough and phlegm appears to have some relevance $\left(G_{4.1}\right.$ and $G_{4.2} ; G_{4.3}$ and $G_{4.4} ; G_{7.1}$ and $G_{7.2}$; $G_{7.3}$ and $\left.G_{7.4}\right)$.

The points mentioned above show that some of the non-bronchitic groups have other complications, such as recent chest illness and/or dyspnoea, which may also impair their ventilatory function as measured by FEV 1 . The average ventilatory function of chronic bronchitics without other complications $\left(G_{5}\right.$ and $\left.G_{6.1}\right)$ is no worse than some groups of nonbronchitics with recent chest illness or dyspnoea, and is indeed better than the three later subgroups of non-bronchitics.

The question of dyspnoea appears to be correlated with episodes of heart trouble $\left(G_{4}\right.$ and $G_{7}$ in Table IV). Although the lung function of subgroup $\mathbf{G}_{4.1}$ is nearer to $\mathbf{G}_{3.3}$ than to $\mathbf{G}_{\mathbf{4} .2}$ (Fig. 1), it is felt that in any combination of subgroups, $G_{4.1}$ would identify itself with $\mathbf{G}_{\mathbf{4 . 2}}$ as both of them have the common complaint of dyspnoea, and have similar prevalence of heart trouble (Table IV and criterion 3). Many subgroups have to be combined because of the small relative frequency of occurrence (criterion 1).

\section{Discussion}

Starting from 24 mutually exclusive sets of responses to the nine questions on respiratory symptoms in the MRC's short questionnaire on chronic bronchitis, it has been possible to recombine subgroups into meaningful combinations.

Table VII summarizes the composition of the seven recommended mutually exclusive groups

TABLE VII

NAMES OF RECOMBINED GROUPS

\begin{tabular}{|c|c|c|c|}
\hline \multicolumn{2}{|c|}{ Groups of Table III } & Name & Code Name \\
\hline G1 & .. & $\begin{array}{l}\text { Non-bronchitic } \\
\text { Grade } 0\end{array}$ & NB 0 \\
\hline $\begin{array}{l}\text { G2, } \\
\text { G3.1, 3.2, } 3.3 \\
\text { G4.1, 4.2, 4.3, } 4.4\end{array}$ & $\begin{array}{l}\cdots \\
\cdots\end{array}$ & $\begin{array}{l}\text { Non-bronchitic } \\
\text { Grade } 1 \\
\text { Non-bronchitic } \\
\text { Grade 2 }\end{array}$ & $\begin{array}{l}\text { NB } 1 \\
\text { NB } 2\end{array}$ \\
\hline 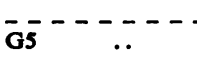 & -- & $\begin{array}{l}\text { Chronic-bronchitic } \\
\text { Grade } 1\end{array}$ & $-\overline{\mathrm{CB}} 1$ \\
\hline G6.1, 6.2, 6.3 & .. & $\begin{array}{l}\text { Chronic-bronchitic } \\
\text { Grade } 2\end{array}$ & CB 2 \\
\hline G7.1, 7.2 .. & .. & $\begin{array}{l}\text { Chronic-bronchitic } \\
\text { Grade } 3\end{array}$ & CB 3 \\
\hline G7.3, $7.4 \ldots$ & . & $\begin{array}{l}\text { Chronic-bronchitic } \\
\text { Grade } 4\end{array}$ & CB 4 \\
\hline
\end{tabular}

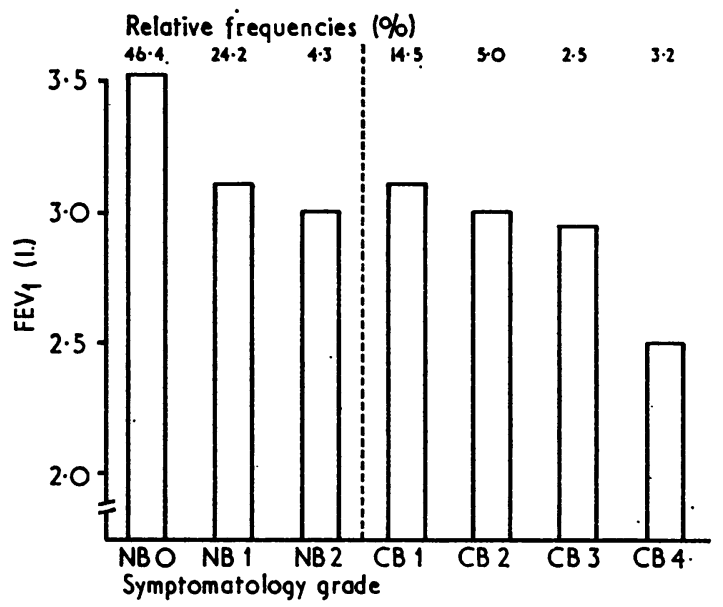

Fio. 2. Adjusted FEV 1 and symptomatology grades, Port Talbot.

derived from the 17 subgroups in Table III. These seven groups will now be referred to by the code names given to them in Table VII. Figure 2 gives the bar chart of $\mathrm{FEV}_{1}$ at standard height and age for the seven mutually exclusive groups of non-bronchitics and bronchitics. It should be recalled that these groupings are based on stated criteria of (1) small relative frequency, (2) lung function differences on FEV 1 adjusted for age and height, and (3) the presence of other respiratory complications (unadjusted for age).

The adjusted values of $\mathrm{FEV}_{1}$ (at age 45 years and height 68 inches) varies from 2.49 litres chronic bronchitis grade 3 (CB4) to $3 \cdot 54$ litres non-bronchitic grade 0 (NB 0), a range of 1.05 litres. Figure 2 shows quite clearly three groups of bronchitis (CB 1, 2, and 3) who are no worse off than two groups of nonbronchitis (NB 1 and 2), and they consist of $33.5 \%$ of the total number with complaints of other respiratory disorders.

An overall comparison on a binary division between non-bronchitics and bronchitics hides the severity of some of the bronchitic groups (Fig. 3).

Studies on the aetiology of bronchitis should ideally compare the suggested grades of bronchitics with the ideal group NB 0 . The ideal group has the lowest prevalence of heart trouble, asthma, and those who have had pneumonia, and consists of about $46 \%$ of the total. The most severe grade of chronic bronchitis (CB 4) has severe impairment of lung function, and about $10 \%$ of those in the grade have the associated complication of asthma or heart trouble and nearly a third have had pneumonia. But they constitute only $3.2 \%$ of the total population surveyed, a seriously limiting factor in 


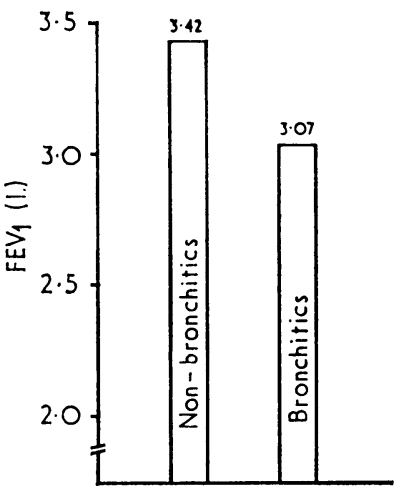

FIG. 3. FEV $\mathrm{F}_{1}$ on a binary division of non-bronchitics and bronchitics.

small-scale investigations on the aetiology of chronic bronchitis. Furthermore, they are likely to be older and most of them are also likely to be smokers. These are additional limiting factors in a statistical analysis searching, for example, for the effect of occupational environments on the severity of chronic bronchitis.

It can be argued that the seven grades were arbitrarily formed with pre-knowledge for the selection criteria mentioned on page 157 . These decisions on the groupings were made for the data collected at Port Talbot, and an independent assessment of these grades can be made with our other survey results at Ebbw Vale.

Figure 4 gives the composite bar chart of $\mathrm{FEV}_{1}$ at the two works. Within each of the grades the ventilatory function at Ebbw Vale is consistently lower than that at Port Talbot. The trends of FEV by grades are remarkably similar at the two works. Table VIII shows the relative frequency distribution of the grades at the two works and also compares

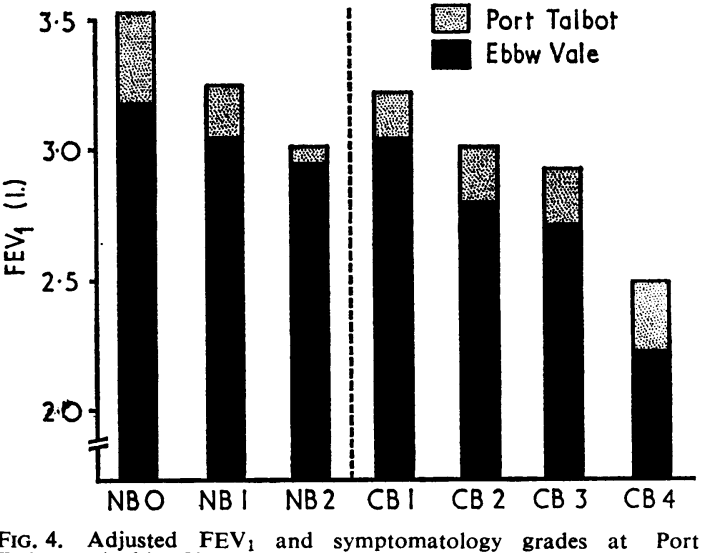

Fig. 4. Adjusted FEV
Talbot and Ebbw Vale.

the prevalence of other respiratory disorders within each of the seven grades. It should be noted that the trend of the prevalence of these other respiratory disorders with the grades at Ebbw Vale are again very similar to those formed with preknowledge of their prevalence at Port Talbot.

The three ventilatory measurements $\mathrm{FEV}_{1}, \mathrm{FVC}$, and FEV \% are highly correlated (Lowe et al. 1968), and of them $\mathrm{FEV}_{1}$ is the most sensitive measure of changes in airways obstruction. Table IX com-? pares the ventilatory functions of the two extreme grades of symptomatology at the two works. The percentage fall is greatest in $\mathrm{FEV}_{1}$ and least in $\mathrm{FEV} \%$.

The use of these seven mutually exclusive grades based on the symptomatology questionnaire of the MRC appears sound, and it is suggested that these grades be used in epidemiological studies for purposes of international comparability and standardization.

TABLE VIII

SYMPTOMATOLOGY GRADES AND PERCENTAGES OF ASTHMA, HEART TROUBLE. AND THOSE WHO HAVE HAD PNEUMONIA

\begin{tabular}{|c|c|c|c|c|c|c|c|c|c|c|}
\hline & \multirow{3}{*}{ Grade } & & & & \multicolumn{6}{|c|}{ Prevalence of Other Diseases (\%) } \\
\hline & & & \multicolumn{2}{|c|}{ Relative Frequency $\%$} & \multicolumn{2}{|c|}{ Asthma } & \multicolumn{2}{|c|}{ Heart Trouble } & \multicolumn{2}{|c|}{ Pneumonia } \\
\hline & & & PT & EV & PT & EV & PT & EV & PT & EV \\
\hline $\begin{array}{lll}\text { NB } & 0 & \ldots \\
\text { NB } & 1 & \ldots \\
\text { NB } & 2 & \end{array}$ & $\begin{array}{l}. \\
\cdots\end{array}$ & $\begin{array}{l}. \\
\because \\
\cdots\end{array}$ & $\begin{array}{r}46 \cdot 4 \\
24 \cdot 2 \\
4 \cdot 3\end{array}$ & $\begin{array}{r}42 \cdot 1 \\
26 \cdot 6 \\
6 \cdot 4\end{array}$ & $\begin{array}{l}1 \cdot 4 \\
2 \cdot 9 \\
4 \cdot 7\end{array}$ & $\begin{array}{l}2 \cdot 3 \\
2 \cdot 5 \\
5 \cdot 6\end{array}$ & $\begin{array}{r}2 \cdot 0 \\
3 \cdot 1 \\
13 \cdot 4\end{array}$ & $\begin{array}{r}2 \cdot 1 \\
3 \cdot 3 \\
12 \cdot 9\end{array}$ & $\begin{array}{l}10 \cdot 8 \\
16 \cdot 3 \\
20 \cdot 1\end{array}$ & $\begin{array}{l}10 \cdot 9 \\
15 \cdot 3 \\
21 \cdot 1\end{array}$ \\
\hline $\begin{array}{lll}\text { CB } & 1 & \ldots \\
\text { CB } & 2 & \cdots \\
\text { CB } & 3 & \ldots \\
\text { CB } & 4 & \ldots\end{array}$ & $\begin{array}{l}. \\
\because \\
\therefore\end{array}$ & $\begin{array}{l}. . \\
\cdots \\
.\end{array}$ & $\begin{array}{r}14 \cdot 5 \\
5 \cdot 0 \\
2 \cdot 5 \\
3 \cdot 2\end{array}$ & $\begin{array}{r}13 \cdot 7 \\
3 \cdot 9 \\
3 \cdot 6 \\
3 \cdot 8\end{array}$ & $\begin{array}{l}3 \cdot 2 \\
6 \cdot 9 \\
4 \cdot 5 \\
9 \cdot 4\end{array}$ & $\begin{array}{r}2.6 \\
5.9 \\
6.5 \\
13.9\end{array}$ & $\begin{array}{r}2 \cdot 3 \\
5 \cdot 6 \\
9 \cdot 8 \\
13 \cdot 5\end{array}$ & $\begin{array}{r}2 \cdot 6 \\
5 \cdot 0 \\
9 \cdot 0 \\
14 \cdot 6\end{array}$ & $\begin{array}{l}16 \cdot 6 \\
21 \cdot 4 \\
16 \cdot 1 \\
34 \cdot 5\end{array}$ & $\begin{array}{l}15 \cdot 8 \\
25 \cdot 6 \\
21 \cdot 3 \\
35 \cdot 2\end{array}$ \\
\hline
\end{tabular}


TABLE IX VENTILATORY FUNCTION

\begin{tabular}{|c|c|c|c|c|c|c|}
\hline \multirow[b]{2}{*}{ Grade } & \multicolumn{2}{|c|}{$\operatorname{FEV}_{1}(1 .)^{*}$} & \multicolumn{2}{|c|}{ FVC(1.)* } & \multicolumn{2}{|c|}{ FEV \%** } \\
\hline & PT & EV & PT & EV & PT & FV \\
\hline $\begin{array}{lll}\text { NB } & 0 & \\
\text { CB } 4 & \ldots\end{array}$ & $\begin{array}{l}3 \cdot 54 \\
2 \cdot 49\end{array}$ & $\begin{array}{l}3 \cdot 17 \\
2 \cdot 21\end{array}$ & $\begin{array}{l}4.49 \\
3.63\end{array}$ & $\begin{array}{l}4 \cdot 21 \\
3 \cdot 43\end{array}$ & $\begin{array}{l}78 \cdot 3 \\
66 \cdot 9\end{array}$ & $\begin{array}{l}74 \cdot 6 \\
63 \cdot 7\end{array}$ \\
\hline$\% \frac{\mathrm{CB} 4}{\mathrm{NB} 0}$ & $70 \cdot 3$ & $69 \cdot 7$ & $80 \cdot 8$ & $81 \cdot 5$ & $85 \cdot 4$ & $85 \cdot 3$ \\
\hline$\%$ Fall & $29 \cdot 7$ & $30 \cdot 3$ & $19 \cdot 2$ & $18 \cdot 5$ & $14 \cdot 6$ & $14 \cdot 7$ \\
\hline
\end{tabular}

* Adjusted to age 45 , ht 68 in. PT = Port Talbot $\mathrm{EV}=$ Ebbw Vale

A generous grant from the Nuffield Foundation, for which we are most grateful, made this investigation possible. It is with pleasure that we acknowledge our indebtedness to Richard Thomas and Baldwins Limited and the Steel Company of Wales Limited for permission to carry out the investigation and to their managements and the Trades Unions for their support while it was in progress. In addition, we are most grateful to Dr. J. G. Jones and Dr. R. B. Body for the help and advice they and their staffs gave us at the two works. Finally, we wish to express our gratitude to Dr. J. Howlett and Mrs.
J. Lay of the Atlas Computer Laboratory, Chilton, Berks, for the invaluable help they and their staff gave us with the analysis of our data.

\section{REFERENCES}

JĘDRYCHOWSKI, W. and KSIĘżYK, M. (1973). Indices of ventilatory lung function (FVC, FEV 1, FEV \%) which adjust for age and height. Brit. J. prev. soc. Med., 27, 121.

KHosLA, T. (1971). Indices of ventilatory measurements. Brit. J. prev. soc. Med., 25, 203.

Lowe, C. R., Pelmear, P. L., Campbell, H., Hitchens, R. A. N., Khosla, T., and KING, T. C. (1968). Bronchitis in two integrated steel works. 1. Ventilatory capacity, age, and physique of non-bronchitic men. Brit. J. prev. soc. Med., 22, 1.

Medical Research Council committee ON THE Aetiology OF Chronic BRONChitis. (1960). Standardized questionaries on respiratory symptoms. Brit. med. J., 2, 1665.

(1966). Questionnaire on Respiratory Symptoms. Obtainable from W. J. Holman Ltd., Dawlish, Devon.

Stuart-HaRris, C. H. (1968). Chronic bronchitis (Parts I, II). Abstr. Wld Med., 42, 649, 737. 